\title{
Occupational Hazards of Halogenated Volatile Anesthetics and their Prevention: Review of the Literature
}

\author{
Béla Tankó, Levente Molnár, Béla Fülesdi and Csilla Molnár
}

Department of Anesthesiology and Intensive Care, University of Debrecen, Egypt

\begin{abstract}
The harmful effect of inhalational anesthetics on the working environment of anesthetists is one of mos controversial areas, where speculations can easily arise. In the present review the authors summarize the possible sources of environmental pollution in the operating theatre with special emphasis on the importance of air suctioning and air conditioning systems. A full-spectrum of the previously published animal and human studies is provided about the possible health hazards of inhalational agents including effects on the central nervous, reproductive and hematologic systems, on the liver functions and also on the carcinogenesis. A list of the proposed measures to decrease pollution to the minimum in the operating theatre environment is provided. It is concluded that according to the present knowledge, the use of inhalational agents may be considered safe if the prescribed limits of halogenated anesthesia gases are met.
\end{abstract}

Keywords: Volatile anesthetics; Halogenated gases

\section{Introduction}

Volatile anesthetics have been used to ensure surgical anesthesia for decades. While the instruments of anesthesia have improved a lot and anesthetic agents have become more and more secure during the past decades, occupational exposure and possible health damage to the operating personnel are still subjects of investigations and matter of debates nowadays. Most human data in this topic are based on epidemiological observations and are usually retrospective. On the one hand, prospective studies are limited due to ethical considerations and other coexisting factors with possible harmful effects (e.g. ionizing radiation, disinfectants, stress, etc.). Despite the fact that the presumed harmful effects of anesthetics are sometimes based on controversial observations, common sense should point toward caution and the determination of the most effective protective measures.

The present literature review aims to provide a comprehensive picture of the topic, summarizing the mechanisms how anesthetic gases leak into the operating room, the potential adverse health effects (particularly with regard to the low level of chronic exposure) and the technical opportunities that allow the effective recognition and quantification of leakage and contamination of the operating room's air. A further, important issue is to resume the duties and safety measures that can radically reduce the degree of exposure.

\section{Inhalational Anesthesia and Halogenated Gases}

Despite the fact that total intravenous anesthesia has become more and more popular in recent years, halogenated gases are still preferred to maintain narcosis. In some cases, such as pediatric anesthesia, or when we are likely to face difficult intubation, inhalational anesthetic techniques are often chosen, in order to avoid respiratory depression.

During the development of anesthesia the spectrum of inhalational anesthetics has gradually changed. Currently sevoflurane, isoflurane, desflurane, enflurane and the less and less popular halothane are used as volatile anesthetics worldwide. Their extensive use can be explained with their favorable pharmacokinetic properties, predictable hemodynamic effects and tissue inert attributes. The colorlessness and highly volatile nature of halogenated anesthetics should be highlighted as common physical properties. When exposed into the air, these gases remain undetected to human senses in most cases, even in fairly high concentrations. For example, half of the population detected halothane in the first place only when its concentration in the air reached 250 ppm, which is 125 folds higher than the maximum recommended level [1].

\section{Possible Locations of Increased Anesthetic Exposition}

Typical locations where staff-members can be exposed to an increased level of inhalational anesthetics are well defined by the literature. These are the followings:

- In operating rooms, where no air conditioning and/or air-suction devices are available. The extraction of volatile anesthetics and removal of mixed gases from surgical rooms into the outer environment is available in most of the operating theaters. In fact, however, such possibilities are not accessible, or little attention is paid in smaller, separate operating theaters (e.g. oral, dental surgery) and in veterinary operating rooms in particular, and thus an increased exposure should be expected.

- It might happen that although air suction and/or exchanger systems are attainable they do not work properly due to scanty inspection and maintenance.

- In post-anesthesia care units, where patients exhale a significant amount of anesthetic gas and the ventilation of the room is improper. Earlier no attention was paid during the design of most hospitals to install air-suction systems with suitable capacity in the awakening rooms. Therefore volatile gases could accumulate in such units.

- Lately an inhalation anesthetic-based sedation technique has become more and more widespread in ICU wards [such as AnaConDa ${ }^{\mathbb{B}}$

*Corresponding author: Béla Fülesdi, Department of Anesthesiology and IC, University of Debrecen, H-4032. Debrecen, Nagyerdei krt 98, Egypt, Tel: 3652255347; E-mail: fulesdi@med.unideb.hu

Received June 06, 2014; Accepted August 05, 2014; Published August 12, 2014

Citation: Tankó B, Molnár L, Fülesdi B, Molnár C (2014) Occupational Hazards of Halogenated Volatile Anesthetics and their Prevention: Review of the Literature. J Anesth Clin Res 5: 426. doi:10.4172/2155-6148.1000426

Copyright: (C 2014 Tankó B, et al. This is an open-access article distributed under the terms of the Creative Commons Attribution License, which permits unrestricted use, distribution, and reproduction in any medium, provided the original author and source are credited. 
system manufactured by Sedana Medical]. With this method it is theoretically possible that staff-members and other patients could be exposed to a certain amount of anesthetics, depending on the air conditioning and air suction circumstances of the ICU.

\section{How can Anesthetic Gases Get into the Air of Operating Rooms?}

The most significant leakage occurs when the gas escapes somewhere between the airway securing instruments and the patient's respiratory tract. Pediatric anesthesia with face masks, laryngeal masks or cuffless tracheal tubes significantly increase the concentration of anesthetic gases in the operating room $[2,3]$. In a recent study, Tankó et al. revealed that during intracerebral surgeries, the evaporated amount of sevoflurane is the highest at the anesthetist's breathing zone, the most important source of this leakage is the patients' mouth [4] and the amount of evaporated gas is independent of the endotracheal tube cuff pressure [5]. It has been also demonstrated that exposure of the anesthesia staff can be decreased by proper positioning of the anesthesia personnel during intracranial surgery [6].

The source of leakage could be any components of the anesthetic machine starting from the vaporizer, where hyper-atmospheric pressure prevails during mechanical ventilation. This section of the anesthetic machine involves the vaporizer, the common line, the limbs of the circuit, the $\mathrm{Y}$-connector, the manual breathing bag - or ventilator bellows - and the $\mathrm{CO}_{2}$ absorber. Imperfect fitting between separate elements, an aperture in the worn out circuit or balloon may become a source of leakage immediately. Malfunctioning unidirectional valves could further increase the rate of leakage, due to the consequential increase in pressure. An additional source could also be the poor fitting of the capnograph's sampling tube.

\section{Adverse Health Effects of Anesthetic Gases}

\section{Observations on experimental animals}

Animal studies provide important data in order to understand the toxicology of inhalational gases and may help to reveal their hidden effects as well. These effects would otherwise develop very slowly under clinical circumstances, due to the chronic exposure to low concentration gases. The results of previous animal studies are summarized below:

Carcinogenesis: Numerous studies have been conducted in animals to test the possible carcinogenic effects of halothane, enflurane and isoflurane [7-9]. In these experiments, the exposure could have last for days or even a year, and in some cases the concentration could have exceeded multiple times the level of anesthetic gases realistically present in operating room. However, experiments with currently used anesthetic gases failed to prove malignant abnormalities from subsequently examined histological samples as a delayed consequence of the exposure. Sevoflurane and desflurane were approved without preliminary examinations, based on their relation to similar halogenated gases and the negative results of the previous studies. Therefore, no data in the literature is available relating to these agents.

Hepatotoxicity: It was proven that long-term exposure of halothane, isoflurane and enflurane in anesthetic concentrations may cause liver damage in mice, rats and guinea pigs, but such harm occurs mainly under special circumstances or adverse conditions (moderate hypoxia or significant malnutrition) [10-13]. However, toxicity is attributable to indirect noxae through metabolites that were biotransformed by the cytochrome P450. In contrast, no obvious organ damage was induced during months of sub-anesthetic exposition (10 ppm halothane, 20 ppm or 200 ppm enflurane) [13,14]. No studies have registered organic lesions caused by the exposure to low or high concentrations of desflurane and sevoflurane.

Mutagenesis: Isoflurane, enflurane and halothane were tested on bacterial cells, mammalian cell cultures and experimental animals in order to detect their possible mutagenic effects [15-18]. The results of DNA analyses consistently suggest that the currently used anesthetics have no mutagenic effects.

Fertility: Gonads of female and male rats or mice were studied after several weeks of low and high concentrations of halogen exposure [halothane, enflurane and isoflurane]. Histological analyses were unable to detect results that would indicate impaired fertility in any cases [18-20].

Teratogenicity: Relatively few studies have examined the impact of halogenated inhalational agents on developmental abnormalities, especially when traceable concentrations of anesthetic were present. Experiments on female rats, exposed to $200 \mathrm{ppm}$ enflurane 8 hours daily, five times a week, have shown no effect on the number of living fetuses, resorption, fetal weight, skeletal abnormalities, and the male/ female ratio of the litter [14]. Similar results were found when female mice have been exposed to $100-1000 \mathrm{ppm}$ enflurane each day for 3 weeks prior mating, during pregnancy or only between the 6th and 15 th gestational days [19]. When pregnant mice were exposed to 60 , 600 or $6000 \mathrm{ppm}$ isoflurane for 4 hours daily, between the 6th and 15th gestational days, decreased fetal weight gain and developmental anomalies were detected, but only with the highest isoflurane concentrations [21]. It has to be mentioned that the negative outcomes of these experiments were presumably not a result of direct gas effect, but a result of the long and rough physiological changes.

\section{Human studies on sub-chronic and chronic effects of anesthetic gases}

Central nervous system: The first reports from the 70s on deteriorating psychomotoric performance of the operating room personnel following nitrous oxide and halothane exposure [22] has opened an ever since active area of research. The majority of studies published so far, almost without exception, have been addressed to examine the concomitant use of nitrous oxide and a halogenated gas, therefore only limited direct data is available about the currently used halogenated agents.

In 1992 Saurel-Cubizolles and associates retrospectively studied, partially confirming the survey results from the 70s, that certain symptoms, such as headaches, dizziness, memory problems, fatigue were more frequent among staff of poorly ventilated operating theaters, especially among co-workers of pediatric surgical rooms [23]. In 1995 Lucchini et al. registered the deterioration of reaction time at the end of the work week among staff of operating rooms who were exposed to enflurane and nitrous oxide, compared to the control group [24]. According to one of their latter study, the same staff performed worse on tests at the end of the work week when narcosis was maintained with gas compared to the total intravenous anesthesia [25]. A subsequent multicenter study suggests that no cognitive or psychomotor dysfunction were detected among operating room personnel when the exposure was held under the recommended level by applying appropriate protective measures [26].

Chronic exposure is assumed to affect not only the mental performance. A postural study of Vouriot et al. showed that central imbalance may develop as a result of prolonged work in operating rooms [27]. 
Liver: It was reported that $25 \%$ of the patients had elevated level of liver enzymes after halothane anesthesia, but in most cases this was not accompanied by any clinical symptoms (type I. halothane hepatotoxicity). Halothane hepatitis is an antigen-antibody associated reaction (type II.) that occasionally causes massive cell necrosis. Genetically determined predisposition is likely to play a role in its pathogenesis (incidence 1:35000). The onset of halothane hepatitis has been reported in some cases as a result of recurring occupational exposure to sub-anesthetic concentrations of halothane $[28,29]$. A very limited number of case reports are available in the literature about isoflurane, enflurane, desflurane or sevoflurane induced hepatitis. The course of the diseases is familiar to the type II. Reaction but the exposure of these gases in sub-anesthetic concentration seems to be completely safe to the personnel. It has to be noted that in a recent prospective study of Casale and co-workers it was demonstrated that health workers exposed to anesthetic gases show higher levels of GOT, GPT, gamma GT and bilirubin levels compared to unexposed controls [30].

Genotoxicity: Initial studies reported contradictory results on the genotoxic effects [chromosome aberrations, sister chromatid exchange, micronucleus assay] of anesthetic gas exposure. Some examinations showed a dose dependent relationship between sister chromatid exchange, micronuclues formation in lymphocytes and gas exposure $[31,32]$. An increased incidence of sister chromatide exchange was reported due to low sevoflurane exposure $(0.2 \mathrm{ppm})$ without the presence of nitrous oxide [33]. It is not entirely clear yet what are the health consequences of these phenomena, or if any other factors may play a role, like ionizing radiation, disinfectant aerosols or stress.

Carcinogenic effects: According to some early epidemiological surveys the incidence of leukemia, lymphoma and other malignant tumors is higher within the exposed population. Closer inspections on these studies show that these subjects were also exposed to various other factors, such as ionizing radiation. Considering the methodological weaknesses of the early researches and the reassuring results of animal studies, the risk of malignant diseases seems unlikely, however it cannot be ruled out entirely.

Reproductive toxicology: The first retrospective epidemiological studies from the 70s reported a correlation between the occupational exposure to anesthetic gases and spontaneous abortions and fetal malformations [34-38], and still serve as a basis for further studies and discussions nowadays. Later, the results of these surveys have been revised and criticized several times [39-41]. The shortcoming of the early studies is that the degree of exposure was undefined, and the results were only associated with the hours spent in operating rooms at best.

A meta-analysis by Boivin and colleagues from 1997 has confirmed that exposure to high gas concentrations serve as a risk factor for abortions, if no air-suction system is available in the operating room [42]. But such outcomes were typical to the early studies. These results are in accordance with studies from recent years that came from the field of children anesthesia [43] and veterinary practice [44,45], where exposures are higher. Further fears related to the use of anesthetic gases, such as malformations, still births; decreased fertility has not been verified during the years. A study published in 2011 raises concerns, where data has been collected from clinical nurse specialists about their labour and possible congenital abnormalities for 10 years. Results showed that exposure to halogenated anesthetics can be associated with certain disorders, most commonly with abnormalities of the heart and epithelium [46]. Being aware of these results, caution and prevention are definitely justifiable.

Pollution: It is little known about the impact of volatile anesthetics on the atmosphere, despite their potentially detrimental effect on global warming. According to Ryan and Nielsen each halogenated anesthetic has harmful impacts, especially desflurane [47]. The global-warming potentials of isoflurane, sevoflurane and desflurane (using $\mathrm{CO} 2$ as reference) are 1230, 1980 and 3714 [48].

Halogenated anesthetics may deplete the ozone layer as they reach the stratosphere, from this point of view, fluorine-containing gases such as auran and desflurane are less harmful than the chlorinecontaining ones like halothane, enflurane and isoflurane [49]. Although inhalational gases contribute to the ozone layer depleting factors with less than $0.03 \%$, the cumulative effect of these gases should be kept in mind, since these compounds have a very long (4-21 years) elimination time [50]. Furthermore, the relative importance of the halogenated anesthetic's impact on the ozone layer could increase in the future as the global utilization of chloro-fluoro-carbons (freons) reduces.

\section{How to Monitor the Degree of Halogenated Anesthetic Gas Exposure?}

Monitoring the air is one of the most important equipment for the assessment of workplace contaminants. The main methods of detecting and measuring the atmospheric concentration of volatile anesthetics will be summarized below. Such data can provide adequate information for building design, working practices and administrative control systems, for the sake of maintain the lowest possible level of gases both in the operating rooms and in post-anesthesia care units.

Air samples should be collected every six months in order to assess the exposure of workers (according to the Occupational Safety and Health Administration) and the effectiveness of reference measurements should be verified as well. Monitoring only the most common agents is sufficient, since the possible corrective measures applied will reduce the amounts of other agents proportionally as well. There are three basic types of sample collection to assess work environment: personal, areal and source samples. Collection of personal samples is the best approach to measure the overall exposure of workers, because it represents gas concentrations of the worker's breathing zone the best during the period of sample collection [4]. This is actually the most preferred method to measure workers' average exposure per unit of time, both in operating theaters and in post-anesthetic care units. Where several people work together in the same job position, same place, shifts and the duration of exposure is also comparable, it is sufficient to gather information regarding exposure from only one representative person.

Areal data collection could be useful to determine the overall contamination of premises, or to compare the contamination of different spaces. Source samples could be useful to detect potential gas leakages, or to ascertain the malfunction of air-suction systems.

Sample collections can be cumulative and "real-time". The latter one displays the direct concentration of anesthetics immediately by using a portable infrared spectrophotometer. The principle is that anesthetic gas molecules absorb infrared rays proportionally to their concentration. Since this method measures and provide feedback immediately, leakages and the effectiveness of controlling measures can be judged promptly.

In Germany and Switzerland Meier and his colleagues used a multi-gas monitor to measure halogenated anesthetics in the breathing 
zone of anesthetists during 114 narcoses. The efficiency of the suction device was studied by detecting the leakage from the expiratory valve of the breathing circuit. The measurements were carried out with low fresh gas flow. The results show that the exposure of personnel could be reduced by 85 percent, if air-suction system was in operation [51].

Another illustrative example of monitoring is when the exposure of the staff showed a $50 \%$ decrease by replacing the air content of the operating room 10 times per hour. The importance and sensitivity of monitoring is emphasized by an observation, where a significant amount (exceeding the recommendations of National Institute for Occupational Safety and Health) of contamination was traceable even with cuffed endotracheal tubes.

Lee and his colleagues found that with standard ventilation the concentration of anesthetics exceed the threshold determined by the National Institute for Occupational Safety and Health. In these cases, the high values could be explained with the suction of the endotracheal tube and the short accidental disconnection of the air-suction device [52].

In order to demonstrate how the anesthetic exposure depends on the quality of air exchanger and suction systems of the operating room, a few examples are summarized in Table 1 [53].

\section{What are the Acceptable Upper Limits of Exposition in the European Union and in the United States?}

In the last decades simultaneously with the publication of studies on the harmful effects of sub-clinical doses of halogens, investigations have emerged to determine the highest permitted levels of exposure. The most appropriate unit of measurement in this case was the atmospheric concentration in parts per million ( $\mathrm{ppm}$ ) averaged to an 8 hours period. The NIOSH (National Institute for Occupational Safety and Health) is the most categorical if it comes to threshold determination. This limits the acceptable atmospheric concentration of all inhalational anesthetics to $2 \mathrm{ppm}$. However, no standards have been set based on

\begin{tabular}{|c|c|}
\hline Air purification method & $\begin{array}{l}\text { The concentration of anesthetic gas in the } \\
\text { air collected from the anesthetist's breathing } \\
\text { zone (ppm) }\end{array}$ \\
\hline Without air conditioning unit & $\begin{array}{l}\text { N2O: } 1000-3000 \\
\text { Halogenated anesthetics: } 10-35\end{array}$ \\
\hline With air conditioning unit & $\begin{array}{l}\text { N2O: } 200-500 \\
\text { Halogenated anesthetics: } 2-5\end{array}$ \\
\hline $\begin{array}{l}\text { With air-suction device, } \\
\text { without air conditioning unit }\end{array}$ & $\begin{array}{l}\text { N2O: } 100-300 \\
\text { Halogenated anesthetics: } 1-4\end{array}$ \\
\hline $\begin{array}{l}\text { With both air suctioning and } \\
\text { conditioning devices }\end{array}$ & $\begin{array}{l}\mathrm{N} 2 \mathrm{O}: 10-35 \\
\text { Halogenated anesthetics: } 0.2 \text { to } 0.5\end{array}$ \\
\hline
\end{tabular}

Table 1: Relationship between how well equipped the operating rooms are and anesthetic gas exposure. (ppm=parts per million).

\begin{tabular}{|l|c|c|c|c|c|c|}
\hline & Sevoflurane & Isoflurane & Enflurane & Desflurane & Halothane & $\mathbf{N}_{\mathbf{2}} \mathbf{O}$ \\
\hline Austria & - & - & - & - & 5 & - \\
\hline Denmark & - & - & 2 & - & 5 & 100 \\
\hline France & - & - & - & - & 2 & - \\
\hline Germany & - & - & 20 & - & 5 & 100 \\
\hline England & - & 50 & 50 & - & 10 & 100 \\
\hline Italy & - & - & - & - & - & 100 \\
\hline Norway & - & 2 & 2 & - & 5 & 100 \\
\hline Sweden & - & 10 & 10 & - & 5 & 100 \\
\hline Switzerland & - & 10 & 10 & - & 5 & 100 \\
\hline United States & 2 & 2 & 2 & 2 & 2 & 25 \\
\hline
\end{tabular}

Table 2: The highest allowed anesthetic gas concentrations in operating rooms. unified consensus in the European Union to the present days. The following table illustrates the situation well since no limits have been determined in a significant number of the most widely used gases by this time (Table 2). The determined levels however have a considerable variation between countries. It should be noted that, unfortunately, the listed limits below have remained only recommendations so far, and none of the countries has integrated them in the category of safety conditions or requirements.

\section{How to Reduce Air Contamination in Operating Theaters?}

\section{Air-suction system}

The air-suction device removes the air/gas mixture emitted through the overflow valves of the breathing circuit's expiratory limb, thereby preventing the mixture to get into the surgical air space. The suction is ensured by the central vacuum, which ideally has a constant strength. The three most important components of the construction are the reservoir, the suction regulator and the negative and positive pressure valves. The reservoir can be a balloon that indicates increased pressure within the system by dilation, or a rigid container with ballvalve, where the rise of the ball shows or could buffer excess pressure in the system. The air flow and air pressure is not constant within the air-suction device, both increases significantly during the expiratory phase. The reservoir is intended to buffer these pressure fluctuations. The pressure valve is activated if 1 .) the central vacuum is too low 2.) the strength of suction is falsely under-regulated, and 3.) the suction is completely closed. The task of the pressure valve is to prevent the development of elevated pressure within the breathing circuit, thus avoid the incidence of barotrauma. The valve could be opened even at a pressure of $5 \mathrm{~cm} \mathrm{H}_{2} \mathrm{O}$. In this case the excess amount of gas is released into the operating room, resulting an increased exposure of the personnel.

\section{Air circulation systems}

Although the suction system remains the most important means of reducing contamination, the air conditioning system is in the second place considering its importance. The fresh air enters at the level of the ceiling and reduces the concentrations of halogens in the operating room partly by dilution and partly by dissipation, and finally become complete by replacing the air itself. As it was pointed out in the monitoring section only the concomitant use of air circulation and suction systems could result a radical reduction in anesthetic gas concentrations of the operating room's air. In post-anesthesia care units, where the exhalation of gases by patients causes the contamination, the air circulation system remains the only effective method to eliminate halogenated anesthetics.

Air exchange equipment with recirculation has become popular nowadays due to economic considerations. Only a fraction of the removed air is emitted into the atmosphere, while the other fraction recirculates. If the same air would return that has left the room, the elimination of anesthetic gases would be ineffective. Therefore the system should be installed in a way that a safe distance is ensured between the operating theater and the spot where air is removed, thus the emitted air won't recirculate.

A system has an optimal capacity if it's capable of replacing the operating theater's air at least 15 times per hour. The direction of air flow is also important. The air inflow should take place close to the ceiling, while the outflow should befall at a lower level. 


\section{Recirculation and Recycling of Halogenated Gases}

Doyle and colleagues has demonstrated during a simulated narcosis that silica zeolite (Deltazite ${ }^{\circledR}$ ) effectively absorbs isoflurane from the suction system [54]. The absorbed agent can be converted and reused with steam extraction and fractional distillation, in this way the emission of anesthetic gases into the atmosphere can be significantly reduced.

Thomasson et al. placed a zeolite filter to the Y-connector, based on the principle of heat-moisture exchanger, thus the amount of gas use has been halved [55]. The development of the so-called anesthetic conserving device was based on this principle [56,57]. The system is closed to the halogenated anesthetics, but opened to the air-oxygen mixture. The gas is administered in liquid form through a perfusor into the device, which is located between the endotracheal tube and the Y-connector. The anesthetic gas is absorbed during exhalation and then released into the lung again during inhalation. In conclusion, the degree of gas consumption and atmosphere contamination could be reduced with $75 \%$, therefore the method could be an effective alternative to low flow systems. The anesthetics conservation unit called Anaconda ${ }^{\circledR}$ was approved for the sedation of ICU patients at the end of the last decade [58].

\section{How to Prevent Exposure of the Operating Personnel?}

Some practical aspects are highlighted below that can help to reduce the exposure of operating room personnel:

- Check the valves and joints of the breathing circuit both with negative and positive pressure. Today's modern anesthetic machines carry out this check-up automatically each time they are put into service as part of the mandatory inspection.

-Make sure that the room's air exchange device works properly.

- Make sure that the suction system is properly connected to the anesthetic machine and to the central vacuum line.

- Check the degree of leakage and the sensitivity of the suction system's pressure valve.

-Refill the vaporizer with anesthetics only between two narcoses.

- Avoid excessive fresh gas flow.

-Disconnect the breathing circuit only when the anesthetic gas has already eliminated from it.

-When using uncuffed endotracheal tubes make sure that the tube is hermetically fill the airways, apply as effective tamponade as possible.

-In case of child-anesthesia if the narcosis is induced with gas, or maintained with inhalational agents through mask it is advisable to use the so-called double mask instead of the traditional one.

\section{In Conclusion}

Neither animal nor human studies have provided any positive results so far about the severe direct organ toxicity of the halogeneted gases, if the exposure was chronic with low concentrations.

In contrast, recently published studies on cognitive functions were unable to report reassuring results. It seems that long-term exposure with high concentrations has an influence on CNS functions such as concentration, memory, endurance, reaction time and coordination. Results from the recent decades show that workers exposed to anesthetics in high concentration are more prone to spontaneous abortion. At the same time it seems more and more certain that the currently used anesthetics have no mutagenic, carcinogenic or clinically significant genotoxic effects. Only the United States has set the level of acceptable atmospheric halogenated particles, which is $2 \mathrm{ppm}$ on average as a maximum from each halogen. Meanwhile members of the European Union have not formed a unified view yet. Nevertheless, the parallel use of air-circulation and suction systems are turned out to be the most effective way to minimize exposure. If both systems work properly the exposure to anesthetic gases could be kept as low as possible. It is still need to be studied what the cumulative effects of the currently accepted, minimal pollution are on the staff of operating rooms on long-term.

\section{References}

1. Hallén B, Ehrner-Samuel H, Thomason M (1970) Measurements of halothane in the atmosphere of an operating theatre and in expired air and blood of the personnel during routine anaesthetic work. See comment in PubMed Commons below Acta Anaesthesiol Scand 14: 17-27.

2. Byhahn C, Strouhal U, Westphal K (2000) Exposure of anesthetists to sevoflurane and nitrous oxide during inhalation anesthesia induction in pediatric anesthesia. See comment in PubMed Commons below Anaesthesio Reanim 25: 12-16.

3. Hoerauf KH, Wallner T, Akça O, Taslimi R, Sessler DI (1999) Exposure to sevoflurane and nitrous oxide during four different methods of anesthetic induction. See comment in PubMed Commons below Anesth Analg 88: 925929

4. Tankó B, Molnár C, Budi T, Peto C, Novák L, et al. (2009) The relative exposure of the operating room staff to sevoflurane during intracerebral surgery. See comment in PubMed Commons below Anesth Analg 109: 1187-1192.

5. Tankó B, Fülesdi B, Novák L, Peto C, Molnár C (2014) Endotracheal tube cuff inflation with and without pressure gauge to minimise sevoflurane pollution during intermittent positive pressure ventilation. Eur J Anaesthesiol 31:172-173

6. Szelei E, Molnár C, Büdi T, Tankó B, Mikos B, et al. (2010) Does isolation technique have any impact on inhalational exposure of neuroanaesthetists to sevoflurane during craniotomies? See comment in PubMed Commons below Eur J Anaesthesiol 27: 994-996.

7. Coate WB, Ulland BM, Lewis TR (1979) Chronic exposure to low concentrations of halothane-nitrous oxide: lack of carcinogenic effect in the rat. See comment in PubMed Commons below Anesthesiology 50: 306-309.

8. Baden JM, Kundomal YR, Mazze RI, Kosek JC (1988) Carcinogen bioassay of isoflurane in mice. See comment in PubMed Commons below Anesthesiology 69: 750-753.

9. Eger El 2nd, White AE, Brown CL, Biava CG, Corbett TH, et al. (1978) A test of the carcinogenicity of enflurane, isoflurane, halothane, methoxyflurane, and nitrous oxide in mice. See comment in PubMed Commons below Anesth Analg 57: 678-694.

10. Kenna JG, Jones RM (1995) The organ toxicity of inhaled anesthetics. See comment in PubMed Commons below Anesth Analg 81: S51-66.

11. Van Dyke RA (1982) Hepatic centrilobular necrosis in rats after exposure to halothane, enflurane, or isoflurane. See comment in PubMed Commons below Anesth Analg 61: 812-819.

12. Shingu K, Eger El 2nd, Johnson BH, Van Dyke RA, Lurz FW, et al. (1983) Hepatic injury induced by anesthetic agents in rats. See comment in PubMed Commons below Anesth Analg 62: 140-145.

13. Stevens WC, Eger El 2nd, White A, Halsey MJ, Munger W, et al. (1975) Comparative toxicities of halothane, isoflurane, and diethyl ether at subanesthetic concentrations in laboratory animals. See comment in PubMed Commons below Anesthesiology 42: 408-419.

14. Green CJ, Monk SJ, Knight JF, Doré C, Luff NP, et al. (1982) Chronic exposure of rats to enflurane 200 p.p.m.: no evidence of toxicity or teratogenicity. See comment in PubMed Commons below Br J Anaesth 54: 1097-1104.

15. Baden JM, Simmon VF (1980) Mutagenic effects of inhalational anesthetics. See comment in PubMed Commons below Mutat Res 75: 169-189.

16. Baden JM, Kundomal YR (1987) Mutagenicity of the combination of a volatile 
Citation: Tankó B, Molnár L, Fülesdi B, Molnár C (2014) Occupational Hazards of Halogenated Volatile Anesthetics and their Prevention: Review of the Literature. J Anesth Clin Res 5: 426. doi:10.4172/2155-6148.1000426

anaesthetic and nitrous oxide. See comment in PubMed Commons below $\mathrm{Br} \mathrm{J}$ Anaesth 59: 772-775

17. Kundomal YR, Baden JM (1985) Mutagenicity of inhaled anesthetics in Drosophila melanogaster. See comment in PubMed Commons below Anesthesiology 62: 305-309.

18. Halsey MJ, Green CJ, Monk SJ, Doré C, Knight JF, et al. (1981) Maternal and paternal chronic exposure to enflurane and halothane: fetal and histological changes in the rat. See comment in PubMed Commons below $\mathrm{Br} \mathrm{J}$ Anaesth 53: $203-215$

19. Wharton RS, Mazze RI, Wilson Al (1981) Reproduction and fetal development in mice chronically exposed to enflurane. See comment in PubMed Commons below Anesthesiology 54: 505-510.

20. Mazze RI (1985) Fertility, reproduction, and postnatal survival in mice chronically exposed to isoflurane. See comment in PubMed Commons below Anesthesiology 63: 663-667.

21. Mazze RI, Wilson AI, Rice SA, Baden JM (1985) Fetal development in mice exposed to isoflurane. See comment in PubMed Commons below Teratology 32: 339-345.

22. Bruce DL, Bach MJ, Arbit J (1974) Trace anesthetic effects on perceptual, cognitive, and motor skills. See comment in PubMed Commons below Anesthesiology 40: 453-458.

23. Saurel-Cubizolles MJ, Estryn-Behar M, Maillard MF, Mugnier N, Masson A et al. (1992) Neuropsychological symptoms and occupational exposure to anaesthetics. See comment in PubMed Commons below Br J Ind Med 49: 276281.

24. Lucchini R, Toffoletto F, Camerino D, Fazioli R, Ghittori S, et al. (1995) Neurobehavioral functions in operating theatre personnel exposed to anesthetic gases. See comment in PubMed Commons below Med Lav 86: 27-33.

25. Lucchini R, Placidi D, Toffoletto F, Alessio L (1996) Neurotoxicity in operating room personnel working with gaseous and nongaseous anesthesia. See comment in PubMed Commons below Int Arch Occup Environ Health 68: 188 192

26. Lucchini R, Belotti L, Cassitto MG, Faillace A, Margonari M, et al. (1997) Neurobehavioral functions in operating theatre personnel: a multicenter study. See comment in PubMed Commons below Med Lav 88: 396-405.

27. Vouriot A, Gauchard GC, Chau N, Nadif R, Mur JM, et al. (2005) Chronic exposure to anesthetic gases affects balance control in operating room personnel. See comment in PubMed Commons below Neurotoxicology 26: 193-198.

28. Sutherland DE, Smith WA (1992) Chemical hepatitis associated with occupational exposure to halothane in a research laboratory. See comment in PubMed Commons below Vet Hum Toxicol 34: 423-424.

29. Otedo AE (2004) Halothane induced hepatitis: case report. See comment in PubMed Commons below East Afr Med J 81: 538-539.

30. Casale T, Caciari T, Rosati MV, Gioffrè PA, Schifano MP, et al. (2014) Anesthetic gases and occupationally exposed workers. See comment in PubMed Commons below Environ Toxicol Pharmacol 37: 267-274.

31. Pasquini R, Scassellati-Sforzolini G, Fatigoni C, Marcarelli M, Monarca S et al. (2001) Sister chromatid exchanges and micronuclei in lymphocytes of operating room personnel occupationally exposed to enfluorane and nitrous oxide. J Environ Pathol Toxicol Oncol. 20:119-126

32. Hoerauf K, Lierz M, Wiesner G, Schroegendorfer K, Lierz P, et al. (1999) Genetic damage in operating room personnel exposed to isoflurane and nitrous oxide. See comment in PubMed Commons below Occup Environ Med 56: 433437.

33. Wiesner G, Schiewe-Langgartner F, Lindner R, Gruber M (2008) Increased formation of sister chromatid exchanges, but not of micronuclei, in anaesthetists exposed to low levels of sevoflurane. See comment in PubMed Commons below Anaesthesia 63: 861-864.

34. Cohen EN, Bellville JW, Brown BW Jr (1971) Anesthesia, pregnancy, and miscarriage: a study of operating room nurses and anesthetists. See comment in PubMed Commons below Anesthesiology 35: 343-347.

35. Cohen EN, Brown BW Jr, Bruce DL, Cascorbi HF, Corbett TH, et al. (1975) A survey of anesthetic health hazards among dentists. See comment in PubMed Commons below J Am Dent Assoc 90: 1291-1296.
36. Knill-Jones RP, Newman BJ, Spence AA (1975) Anesthetic practice and pregnancy. Controlled survey of male anaesthetists in the United Kingdom. See comment in PubMed Commons below Lancet 2: 807-809.

37. Pharoah PO, Alberman E, Doyle P, Chamberlain G (1977) Outcome of pregnancy among women in anaesthetic practice. See comment in PubMed Commons below Lancet 1: 34-36

38. Cohen EN, Gift HC, Brown BW, Greenfield W, Wu ML, et al. (1980) Occupational disease in dentistry and chronic exposure to trace anesthetic gases. See comment in PubMed Commons below J Am Dent Assoc 101: 21-31.

39. Buring JE, Hennekens CH, Mayrent SL, Rosner B, Greenberg ER, et al. (1985) Health experiences of operating room personnel. See comment in PubMed Commons below Anesthesiology 62: 325-330.

40. Vessey MP (1978) Epidemiological studies of the occupational hazards of anaesthesia--a review. See comment in PubMed Commons below Anaesthesia 33: $430-438$

41. Ferstandig LL (1978) Trace concentrations of anesthetic gases: a critical review of their disease potential. See comment in PubMed Commons below Anesth Analg 57: 328-345.

42. Boivin JF (1997) Risk of spontaneous abortion in women occupationally exposed to anaesthetic gases: a meta-analysis. See comment in PubMed Commons below Occup Environ Med 54: 541-548.

43. Gauger VT, Voepel-Lewis T, Rubin P, Kostrzewa A, Tait AR (2003) A survey of obstetric complications and pregnancy outcomes in paediatric and nonpaediatric anaesthesiologists. See comment in PubMed Commons below Paediatr Anaesth 13: 490-495.

44. Shirangi A, Fritschi L, Holman CD (2008) Maternal occupational exposures and risk of spontaneous abortion in veterinary practice. See comment in PubMed Commons below Occup Environ Med 65: 719-725

45. Shirangi A, Fritschi L, Holman CD (2009) Associations of unscavenged anesthetic gases and long working hours with preterm delivery in female veterinarians. See comment in PubMed Commons below Obstet Gynecol 113: 1008-1017.

46. Teschke K, Abanto Z, Arbour L, Beking K, Chow Y, et al. (2011) Exposure to anesthetic gases and congenital anomalies in offspring of female registered nurses. See comment in PubMed Commons below Am J Ind Med 54: 118-127.

47. Ryan SM, Nielsen CJ (2010) Global warming potential of inhaled anesthetics: application to clinical use. See comment in PubMed Commons below Anesth Analg 111: 92-98.

48. Forster P, Ramaswamy V, Artaxo P (2007) Changes in Atmospheric Constituents and in Radiative Forcing. In: Solomon S, Qin D, Manning M, et al., (Eds.) Climate Change 2007: The Physical Science Basis. Contribution of Working Group I to the Fourth Assessment Report of the Intergovernmenta Panel on Climate Change. (Edn.) Cambridge University Press, United States

49. Ishizawa $Y$ (2011) Special article: general anesthetic gases and the global environment. See comment in PubMed Commons below Anesth Analg 112 213-217.

50. Langbein T, Sonntag H, Trapp D, Hoffmann A, Malms W, et al. (1999) Volatile anaesthetics and the atmosphere: atmospheric lifetimes and atmospheric effects of halothane, enflurane, isoflurane, desflurane and sevoflurane. $\mathrm{Br} J$ Anaesth 82:66-73

51. Meier A, Jost M, Rüegger M, Knutti R, Schlatter C (1995) [Narcotic gas burden of personnel in pediatric anesthesia]. See comment in PubMed Commons below Anaesthesist 44: 154-162.

52. Li SH, Li SN, Shih HY, Yi HD, Chiang CY (2002) Personnel exposure to waste sevoflurane and nitrous oxide during general anesthesia with cuffed endotracheal tube. See comment in PubMed Commons below Acta Anaesthesiol Sin 40: 185-190.

53. Doyle DJ, Byrick R, Filipovic D, Cashin F (2002) Silica zeolite scavenging of exhaled isoflurane: a preliminary report. See comment in PubMed Commons below Can J Anaesth 49: 799-804.

54. Rejger (1975) Acta Anesthesiologica Belgica 26: 174-181.

55. Thomasson R, Luttropp $\mathrm{HH}$, Werner O (1989) A reflection filter for isoflurane and other anaesthetic vapours. See comment in PubMed Commons below Eur J Anaesthesiol 6: 89-94.

56. Enlund M, Wiklund L, Lambert $\mathrm{H}$ (2001)A new device to reduce the consumption 
Citation: Tankó B, Molnár L, Fülesdi B, Molnár C (2014) Occupational Hazards of Halogenated Volatile Anesthetics and their Prevention: Review of the Literature. J Anesth Clin Res 5: 426. doi:10.4172/2155-6148.1000426

Page 7 of 7

of a halogenated anaesthetic agent. See comment in PubMed Commons below Anaesthesia 56: 429-432.

57. Tempia A, Olivei MC, Calza E, Lambert H, Scotti L et al. (2003) The anesthetic conserving device compared with conventional circle system used under different flow conditions for inhaled anesthesia. Anesth Analg 96:1056-1061
58. Enlund M, Kietzmann D, Bouillon T, Züchner K, Meineke I (2008) Population pharmacokinetics of sevoflurane in conjunction with the AnaConDa: toward target-controlled infusion of volatiles into the breathing system. See comment in PubMed Commons below Acta Anaesthesiol Scand 52: 553-560.
Citation: Tankó B, Molnár L, Fülesdi B, Molnár C (2014) Occupational Hazards of Halogenated Volatile Anesthetics and their Prevention: Review of the Literature. J Anesth Clin Res 5: 426. doi:10.4172/2155-6148.1000426
Submit your next manuscript and get advantages of OMICS Group submissions

Unique features:

- User friendly/feasible website-translation of your paper to 50 world's leading languages

Audio Version of published paper

Digital articles to share and explore

Special features:

350 Open Access Journals

30,000 editorial team

21 days rapid review proces

Quality and quick editorial, review and publication processing

Indexing at PubMed (partial), Scopus, EBSCO, Index Copernicus and Google Scholar etc

Sharing Option: Social Networking Enabled

- Authors, Reviewers and Editors rewarded with online Scientific Credits

Better discount for your subsequent articles

Submit your manuscript at: http://www.omicsonline.org/submission 